\title{
New ideas on the systematics of Gliridae (Rodentia, Mammalia)
}

\author{
Matthijs FREUDENTHAL ${ }^{I^{*}}$ \& Elvira MARTÍN-SUÁREZ
}

\begin{abstract}
${ }^{1}$ Departamento de Estratigrafía y Paleontología, Campus Fuentenueva, Universidad de Granada, 18071 Granada, Spain, and Netherlands Centre for Biodiversity, Naturalis, P.O. Box 9517, NL-2300 RA Leiden, The Netherlands; mfreuden@ugr.es

${ }^{2}$ Departamento de Estratigrafía y Paleontología, Campus Fuentenueva, Universidad de Granada, 18071 Granada, Spain; elvirams@ugr.es

* Corresponding author
\end{abstract}

Freudenthal, M. \& Martín-Suárez, E. 2013. New ideas on the systematics of Gliridae (Rodentia, Mammalia). [Nuevas ideas sobre la sistemática de Gliridae (Rodentia, Mammalia)]. Spanish Journal of Palaeontology, 28 (2), 239-252.

\begin{abstract}
Extant members of the family Gliridae lack a caecum and are not capable of digesting hard (cellulose) plant material. We assume that they did have a caecum at some time in the past and consequently may have had a different diet. We think that during the period of their maximum diversity in the Early Miocene, about $16 \mathrm{My}$ ago, they still possessed the caecum, which allowed for a much greater variety in diet, as may be reflected by the existence of hypsodont taxons, and that they lost it afterwards. It is, however, unlikely that the three recent subfamilies that existed in the Miocene, Glirinae, Myomiminae and Dryomyinae, lost the caecum independently; the alternative is that all modern glirids are derived from one single Middle Miocene species. If that is true the few occurrences of the recent genera in MN4 or older, should be transferred to other, eventually new, genera. This is consistent with the fact that the distributions of the extant genera before MN9 are discontinuous and that, except for Muscardinus, they are absent in MN6-MN8 (14-11 My ago).
\end{abstract}

Keywords: Gliridae, Rodentia, systematics.

\section{RESUMEN}

Los glíridos actuales (lirones) no son capaces de digerir la celulosa porque carecen de ciego intestinal. Entre los glíridos fósiles hay mayores diferencias en los patrones dentarios, existen incluso taxones con los dientes de corona alta (hipsodontos). Por ello suponemos que tenían dietas más variadas y también que tenían ciego durante el período de su máxima diversidad en el Mioceno temprano, hace aproximadamente 16 millones de años. Posteriormente lo perdieron. Pero es poco probable que las tres subfamilias actuales que existían en el Mioceno, Glirinae, Myomiminae y Dryomyinae, perdieran el ciego independientemente. La alternativa es que todos los lirones actuales provienen de una sola especie del Mioceno Medio. Si es así, las pocas especies de los géneros actuales conocidas de MN4 y anterior deben ser transferidas a otros géneros, en su caso nuevos. Esto es consistente con el hecho de que las distribuciones de los géneros actuales son discontinuas y no están representados (excepto Muscardinus) entre 14 y 11 millones de años.

Palabras clave: Gliridae, Rodentia, sistemática. 


\section{INTRODUCTION}

Gliridae Muirhead, 1819 is a rodent family with a mainly European distribution and a limited number of extant species. Throughout the Oligocene glirids are constantly present and quite diverse in European faunas. With the extinction of Theridomorpha and Oligocene Cricetidae (Eucricetodontinae and Pseudocricetodontinae) at the Oligocene/Miocene transition they reach their maximum species diversity in the Early Miocene, and at that time they often are the dominant family, with up to $90 \%$ of the rodent specimens. From MN5 onwards the new Cricetidae become the dominant group and the number of glirid species and their specimen frequency decrease (see Daams \& de Bruijn, 1995, figs 2, 9 and 10).

Tullberg (1899) was the first to recognize that extant Gliridae lack a caecum and this was confirmed by later workers, e.g., Storch (1995). The caecum is a blind sac, placed at the transition from the small intestine to the large intestine, containing bacteria that are capable of fermenting hard plant material (cellulose) through the enzyme cellulase. This hindgut fermentation is typical of Perissodactyla and Rodentia, among others. The size of the caecum is directly related with the percentage of cellulose in the food; it is large in herbivores and small in carnivores. Laboratory experiments have shown that the size of the caecum in rodents increases with the amount of cellulose in the food (Dominguez-Bello \& Robinson, 1991).

The lack of the caecum means that extant Gliridae are not capable of digesting hard (cellulose) plant material; they feed on soft plant tissue, nuts and seeds, young birds, eggs and invertebrates. It is hard to give preferences because the diet is determined by the seasonal availability of food sources.

The only available fact about the diet of fossil glirids is the paper by Storch \& Seiffert (2007), who concluded that the Eocene Eogliravus wildi Hartenberger, 1971, had a similar diet as extant Gliridae, but that does not mean that all fossil glirids had that same diet. It seems reasonable to suppose that they did have a caecum at some time in the past and consequently may have had a different diet.

Contrary to Gliridae, all other extant rodents for which data are available do have a caecum. During the period of their maximum diversity, around MN4/5, about 16 to 15 My ago, Gliridae may represent up to $90 \%$ of the rodent fauna and almost certainly occupied all niches and used all available food sources. Consequently, at that time they must have had the caecum, which allowed for a much greater variety in diet, as may be reflected by the existence of hypsodont taxons, like Armantomys de Bruijn, 1966a. Hypsodonty is strongly correlated with the digestion of hard plant material (Daams \& van der Meulen, 1984; Kaiser et al., 2011). The latter authors said about Armantomys: "The dental morphology and the food- abraded enamel in the valleys and dentine exposed in the ridges indicate adaptation to very tough plant material".

According to the current classification (Daams \& de Bruijn, 1995) the three subfamilies Glirinae, Myomiminae and Dryomyinae are already present in the Early Miocene. In our opinion it is unconceivable that their Miocene members, when evolving towards their extant relatives, would have lost the caecum independently.

The alternative is a completely new concept of glirid evolution, in which the modern species are derived from one single Middle Miocene genus, e.g., a Microdyromys de Bruijn, 1966a. The few occurrences of the recent genera (see Fig. 1) in MN4 or older should be transferred to other, eventually new, genera. Table 1 gives the FAD and LAD (first and last appearance dates) of a selection of genera; discontinuous distributions are represented on separate lines. Bibliographic references for these data are given in Table 2.

\section{MATERIAL AND METHODS}

The current classification (Daams \& de Bruijn, 1995, emended by Freudenthal \& Martín-Suárez, 2007b) recognizes seven subfamilies: Glirinae, Dryomyinae, Myomiminae, Graphiurinae, and the extinct Gliravinae, Glamyinae and Bransatoglirinae. We use that classification as the basis of our work.

Several authors have described cranial characters of fossil glirids, e.g., Vianey-Liaud (1989), but systematics of fossil glirids is mainly based on the morphology of the dental pattern: number and position of ridges, connections between ridges, and concavity, e.g., Daams \& de Bruijn (1995) explicitly state: "The criterion used for subdividing the Gliridae is the morphology of the cheek teeth because this is the only character known for all taxa".

Classification of recent glirids is based on a wide variety of characters, like cranial morphology, dental pattern, incisor enamel, and soft tissue like mastication muscles, genital morphology, and auditory region (Wahlert et al., 1993; Storch, 1995). A recent development is molecular distance (Montgelard et al., 2003).

In this paper we focus on the absence of the caecum, which seems to be the only character shared by all extant Gliridae. Through the analysis of the fossil record (time range, discontinuous distribution, number of species, relative frequency and hypsodonty) we try to estimate the moment they lost the caecum.

Montgelard et al. (2003) gave ages for the origin of the modern genera on the basis of molecular distance. Her calculations are based on a supposed base age of 50 My (Eocene MP10, the age of the oldest known glirid, Eogliravus wildi). We recalculated their results, multiplying them by 0.33 , for a base age of $16 \mathrm{My}$, which we postulate as the age at which glirids still had the caecum. 


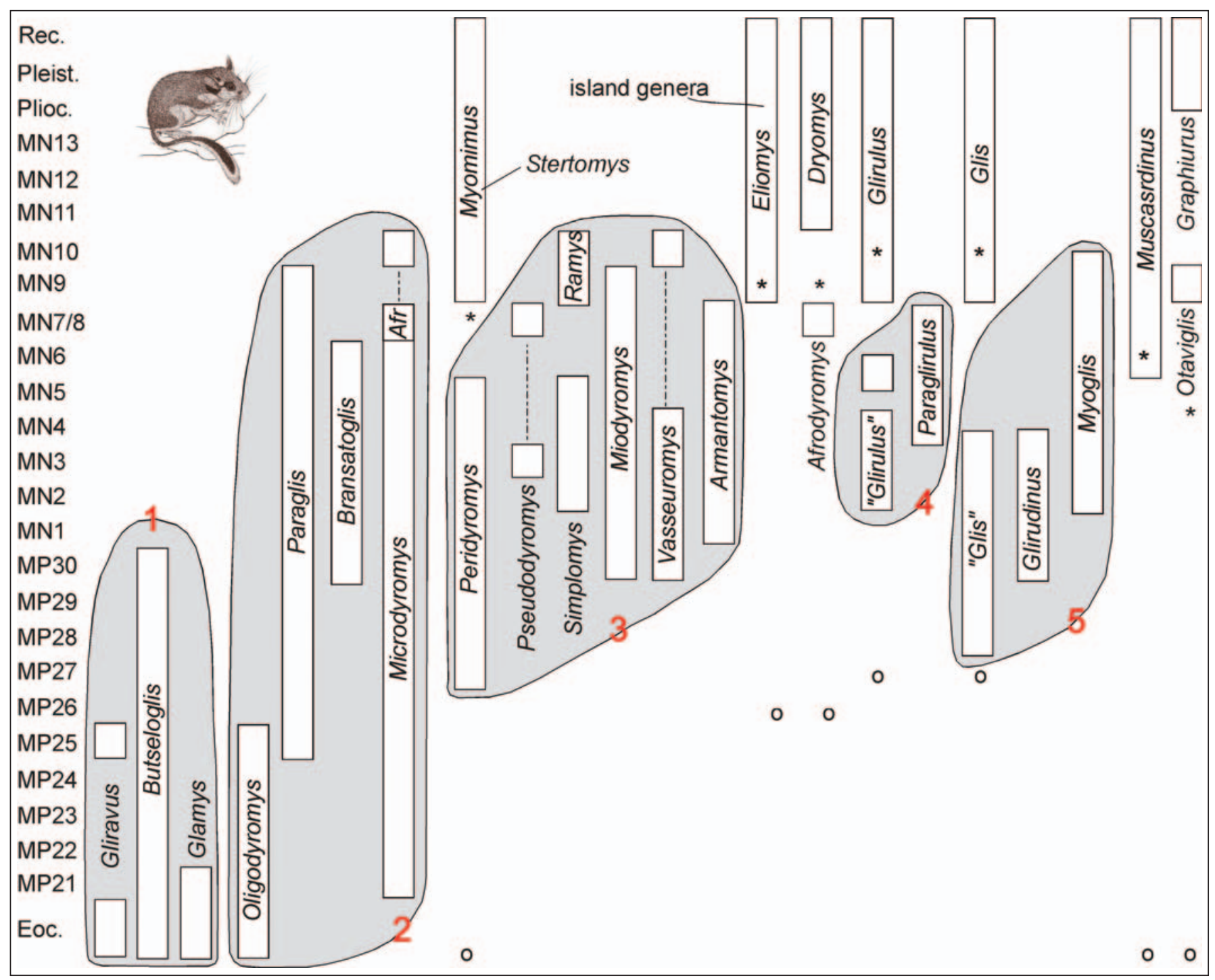

Figure 1. Distribution of glirid genera. The time of appearance of the extant genera based on the molecular clock is indicated by asterisks (base age $16 \mathrm{My}$ ) and circles (base age $50 \mathrm{My}$ ). Grey fields represent subfamilies. 1: Gliravinae and Glamyinae; 2: Bransatoglirinae; 3: Peridyromyinae; 4 and 5: unnamed subfamilies.

For relative ages we use MP units (Biochrom'97, 1997) and MN units (de Bruijn et al., 1992). Absolute ages are based on ATNTS (Lourens et al., 2004).

\section{SYSTEMATIC PALAEONTOLOGY}

In the following we will analyze the stratigraphic record and the contents of the extant genera, and of Microdyromys, which we consider to be the ancestor of recent Gliridae. Records of Glis, Glirulus and Myomimus from MN4 and older are transferred to other genera.

Subfamily Bransatoglirinae Daams \& de Bruijn, 1995

Genus Microdyromys de Bruijn, 1966a
Microdyromys appears in MP21, possibly derived from an Eocene Gliravus Stehlin \& Schaub, 1951 or Glamys Vianey-Liaud, 1989, and is continuously present from MP21 through MN6. If Afrodyromys ambiguus is a Microdyromys (see Jaeger, 1977a) its distribution is extended to MN7/8. The genus reappears in MN10 with Microdyromys sinuosus (Alvarez-Sierra, 1986) and possibly ?Afrodyromys chaabi Jaeger, 1977b, though we can't be sure that these MN10 occurrences really belong to this genus.

In MP27 it gives rise to Peridyromys Stehlin \& Schaub, 1951 , which is the origin of the other genera that were previously placed in Myomiminae and which we group in the new subfamily Peridyromyinae. Another possibility is that Peridyromys is derived from Butseloglis VianeyLiaud, 2004 (Fig. 2). 
Table 1. FAD's and LAD's (first and last appearance date) of selected genera of Gliridae.

\begin{tabular}{|c|c|c|c|c|c|c|}
\hline \multirow[t]{2}{*}{ GENUS } & \multicolumn{2}{|r|}{ FAD } & \multicolumn{2}{|r|}{ LAD } & \multirow[t]{2}{*}{ FAD } & \multirow[t]{2}{*}{ LAD } \\
\hline & SPECIES & LOCALITY & SPECIES & LOCALITY & & \\
\hline Graphiurus & sp. & Langebaanweg & spp. & Recent & Plioc. & Recent \\
\hline Otaviglis & daamsi & Harasib & & & MN9 & \\
\hline Dryomys & $\mathrm{sp}$ & Dorn-Dürkheim & nitedula & Recent & MN11 & Recent \\
\hline Eliomys & assimilis & Hammerschmiede & quercinus & Recent & MN9 & Recent \\
\hline Muscardinus & thaleri & Manchones & avellanarius & Recent & MN6 & Recent \\
\hline Eomuscardinus & sansaniensis & Sansan & cf. vallesiensis & Castell de Barbera & MN6 & MN7/8 \\
\hline Eomuscardinus & vallesiensis & Can Llobateres & helleri & Gundersheim 4 & MN9 & MN15 \\
\hline Glirulus & conjunctus & Marktl & japonicus & Recent & MN9 & Recent \\
\hline Glirulus & daamsi & Çandir & & & MN5/6 & \\
\hline Glirulus & aff. ekremi & Harami 1 & minor & Petersbuch 2 & MN2 & MN4A \\
\hline Paraglirulus & agelakisi & Aliveri & werenfelsi & Anwil & MN4A & $\mathrm{MN} 7 / 8$ \\
\hline Glis & vallesiensis & Ballestar & glis & Recent & MN9 & Recent \\
\hline Glis & guerbuezi & Kocayarma & galitopouli & Aliveri & MP28 & MN4A \\
\hline Glirudinus & glirulus & Gunzenheim & undosus & Erkertshofen & MP30 & MN4A \\
\hline Myoglis & sp. & Lespignan & meini & Soblay & MN2B & MN10 \\
\hline Miodyromys & hugueneyae & Fraga 11 & hamadryas & Can Ponsich & MP30 & MN9 \\
\hline Myomimus & dehmi & Pedregueras $2 \mathrm{C}$ & personatus & Recent & MN9 & Recent \\
\hline Myomimus & sp. & Keseköy & $\mathrm{sp}$ & Çandir & MN3 & $\mathrm{MN} 5 / 6$ \\
\hline Peridyromys & murinus & Mirambueno 1 & sondaari & Vargas 2B & MP27 & MN5 \\
\hline Ramys & perezi & Ampudia 9 & multicrestatus & Torremormojón 1 & MN9 & MN10 \\
\hline Simplomys & aljaphi & Montaigu-le-Blin & simplicidens & Las Umbrías 17 & MN2A & MN5 \\
\hline Vasseuromys & bergasensis & Bergasa & cristinae & Pico del Fraile 2 & MP30 & $\mathrm{MN} 4 / 5$ \\
\hline Vasseuromys & pannonicus & Széchenyi Hill & & & MN10 & MN10 \\
\hline Armantomys & bijmai & Santa Cilia & tricristatus & Escobosa & MN1 & MN7/8 \\
\hline Pseudodryomys & rex & Torremormojón 6B & & & MN7/8 & \\
\hline Pseudodryomys & ibericus & Ateca 1 & & & MN3 & \\
\hline Oligodyromys & bahloi & Headon Hill 3 & moyai & Sineu & MP17 & MP25 \\
\hline Paraglis & fugax & Mirambueno 4B & astaracensis & Belchatów A & MP25 & MN9 \\
\hline Bransatoglis & concavidens & Coderet & mayri & Sandelzhausen & MP30 & MN6 \\
\hline Microdyromys & misonnei & Hoogbutsel & complicatus & Sansan & MP21 & MN6 \\
\hline Microdyromys & sinuosus & Ampudia 3 & & & MN10 & MN10 \\
\hline Afrodyromys & ambiguus & Beni Mellal & chaabi & Oued Zra & MN7/8 & MN10 \\
\hline Gliravus & pyrenaicus & Sossis 1 & & & MP17 & MP17 \\
\hline Gliravus & caracensis & Pareja & & & MP25 & MP25 \\
\hline Glamys & robiacensis & Robiac Sud & olallensis & Olalla 4A & MP16 & MP21 \\
\hline Butseloglis & daamsi & Headon Hill 2 & bruijni & Coderet & MP17 & MP30 \\
\hline
\end{tabular}

Subfamily Glirinae Muirhead, 1819

Genus Glis Brisson, 1762

Glis is recorded from MP28 to Recent, with an important gap in MN5-MN8. The oldest record after the gap is G. vallesiensis Agustí, 1981 from Ballestar (MN9), which may be considered a true Glis, but the older records from MP28 to MN4 in our opinion represent a different genus. One of these, Glis truyolsi Daams, 1976 from Cetina de Aragón (MN2) was placed in Myoglis Baudelot, 1965 by Werner (1994) and that may be a good solution for the other Glis species from MN4 and older: G. apertus Mayr, 1979; G. galitopouli van der Meulen \& de Bruijn, 1982; G. guerbuezi Ünay-Bayraktar, 1989; G. major de Bruijn \& Rümke, 1974 and G. transversus Ünay, 1994. Myoglis, Glirudinus de Bruijn, 1966a and Heteromyoxus
Dehm, 1938 form a subfamily of their own, different from Glirinae.

This hypothesis is supported by Daams \& de Bruijn (1995), who stated: "We can now trace Glis to the Oligocene, and dispute about generic allocation is whether or not to include Glis guerbuezi Ünay- Bayraktar, 1989 from the Middle Oligocene of Turkey into Glis. For a rodent genus a stratigraphic range of more than thirty million years seems very long and is probably not biologically correct, but the effect of our parsimonious knowledge of fossil species."

\section{Genus Muscardinus Kaup, 1829}

Aguilar \& Lazzari (2006) described Muscardinus sansaniensis (Lartet, 1851) from MN4/5 of Blanquatère 1. 
Table 2. Bibliographic references for the data in Table 1.

\begin{tabular}{|c|c|c|}
\hline SPECIES & LOCALITY & REFERENCE \\
\hline Afrodyromys ambiguus & Beni Mellal & Lavocat, 1961 \\
\hline Afrodyromys chaabi & Oued Zra & Jaeger, 1977b \\
\hline Armantomys bijmai & Santa Cilia & Lacomba \& Martínez-Salanova, 1988 \\
\hline Armantomys tricristatus & Escobosa & Daams, 1990 \\
\hline Bransatoglis concavidens & Coderet & Hugueney, 1967 \\
\hline Bransatoglis mayri & Sandelzhausen & Rabeder, 1984 \\
\hline Butseloglis bruijni & Coderet & Hugueney, 1967 \\
\hline Butseloglis daamsi & Headon Hill 2 & Bosma \& de Bruijn, 1982 \\
\hline Dryomys sp. & Dorn-Dürkheim & Franzen \& Storch, 1975 \\
\hline Eliomys assimilis & Hammerschmiede & Mayr, 1979 \\
\hline Eomuscardinus helleri & Gundersheim 4 & García-Alix et al., 2008a \\
\hline Eomuscardinus sansaniensis & Sansan & Daams, 1985 \\
\hline Eomuscardinus vallesiensis & Can Llobateres & García-Alix et al., 2008a \\
\hline Glamys olallensis & Olalla 4A & Freudenthal, 1996 \\
\hline Glamys robiacensis & Robiac Sud & Vianey-Liaud, 1994 \\
\hline Gliravus caracensis & Pareja & Daams et al., 1989 \\
\hline Gliravus pyrenaicus & Sossis 1 & Agustí \& Arcas, 1997 \\
\hline Glirudinus glirulus & Gunzenheim & Dehm, 1935 \\
\hline Glirudinus undosus & Erkertshofen & Mayr, 1979 \\
\hline Glirulus aff. ekremi & Harami 1 & Ünay, 1994 \\
\hline Glirulus conjunctus & Marktl & Mayr, 1979 \\
\hline Glirulus daamsi & Çandir & de Bruijn et al., 2003 \\
\hline Glirulus minor & Petersbuch 2 & Wu, 1993 \\
\hline Glis galitopouli & Aliveri & van der Meulen \& de Bruijn, 1982 \\
\hline Glis guerbuezi & Kocayarma & Ünay-Bayraktar, 1989 \\
\hline Glis vallesiensis & Ballestar & Agustí, 1981 \\
\hline Graphiurus sp. & Langebaanweg & Pocock, 1976 \\
\hline Microdyromys complicatus & Sansan & Daams \& de Bruijn, 1995 \\
\hline Microdyromys misonnei & Hoogbutsel & Freudenthal \& Martín-Suárez, 2007a \\
\hline Microdyromys sinuosus & Ampudia 3 & Alvarez Sierra, 1986 \\
\hline Miodyromys hamadryas & Can Ponsich & Daams \& de Bruijn, 1995 \\
\hline Miodyromys hugueneyae & Fraga 11 & Agustí \& Arbiol, 1989 \\
\hline Muscardinus thaleri & Manchones & de Bruijn, 1966a \\
\hline Myoglis meini & Soblay & Nemetschek \& Mörs, 2003 \\
\hline Myoglis sp. & Lespignan & Aguilar, 1974 \\
\hline Myomimus dehmi & Pedregueras $2 \mathrm{C}$ & de Bruijn, 1966b \\
\hline Myomimus sp. & Çandir & de Bruijn et al., 2003 \\
\hline Myomimus sp. & Keseköy & Ünay, 1994 \\
\hline Oligodyromys bahloi & Headon Hill 3 & Hugueney \& Adrover, 1990 \\
\hline Oligodyromys moyai & Sineu & Hugueney \& Adrover, 1990 \\
\hline Otaviglis daamsi & Harasib & Mein et al., 2000 \\
\hline Paraglirulus agelakisi & Aliveri & van der Meulen \& de Bruijn, 1982 \\
\hline Paraglirulus werenfelsi & Anwil & Engesser, 1972 \\
\hline Paraglis astaracensis & Belchatów A & Freudenthal \& Martín-Suárez, 2007b \\
\hline Paraglis fugax & Mirambueno 4B & Freudenthal \& Martín-Suárez, 2007b \\
\hline Peridyromys murinus & Mirambueno 1 & Freudenthal, 1997 \\
\hline Peridyromys sondaari & Vargas $2 \mathrm{~B}$ & Daams, 1999 \\
\hline Pseudodryomys ibericus & Ateca 1 & de Bruijn, 1966a \\
\hline Pseudodryomys rex & Torremormojón 6B & García Moreno, 1986 \\
\hline Ramys multicrestatus & Torremormojón 1 & García Moreno \& López Martínez, 1986 \\
\hline Ramys perezi & Ampudia 9 & Alvarez Sierra, 1986 \\
\hline Simplomys aljaphi & Montaigu-le-Blin & García-Paredes et al., 2009 \\
\hline Simplomys simplicidens & Las Umbrías 17 & García-Paredes et al., 2009 \\
\hline Vasseuromys bergasensis & Bergasa & Ruiz Sánchez et al. (in prep.) \\
\hline Vasseuromys cristinae & Pico del Fraile 2 & Ruiz-Sánchez et al., 2012 \\
\hline Vasseuromys pannonicus & Széchenyi Hill & Kretzoi, 1980 \\
\hline
\end{tabular}




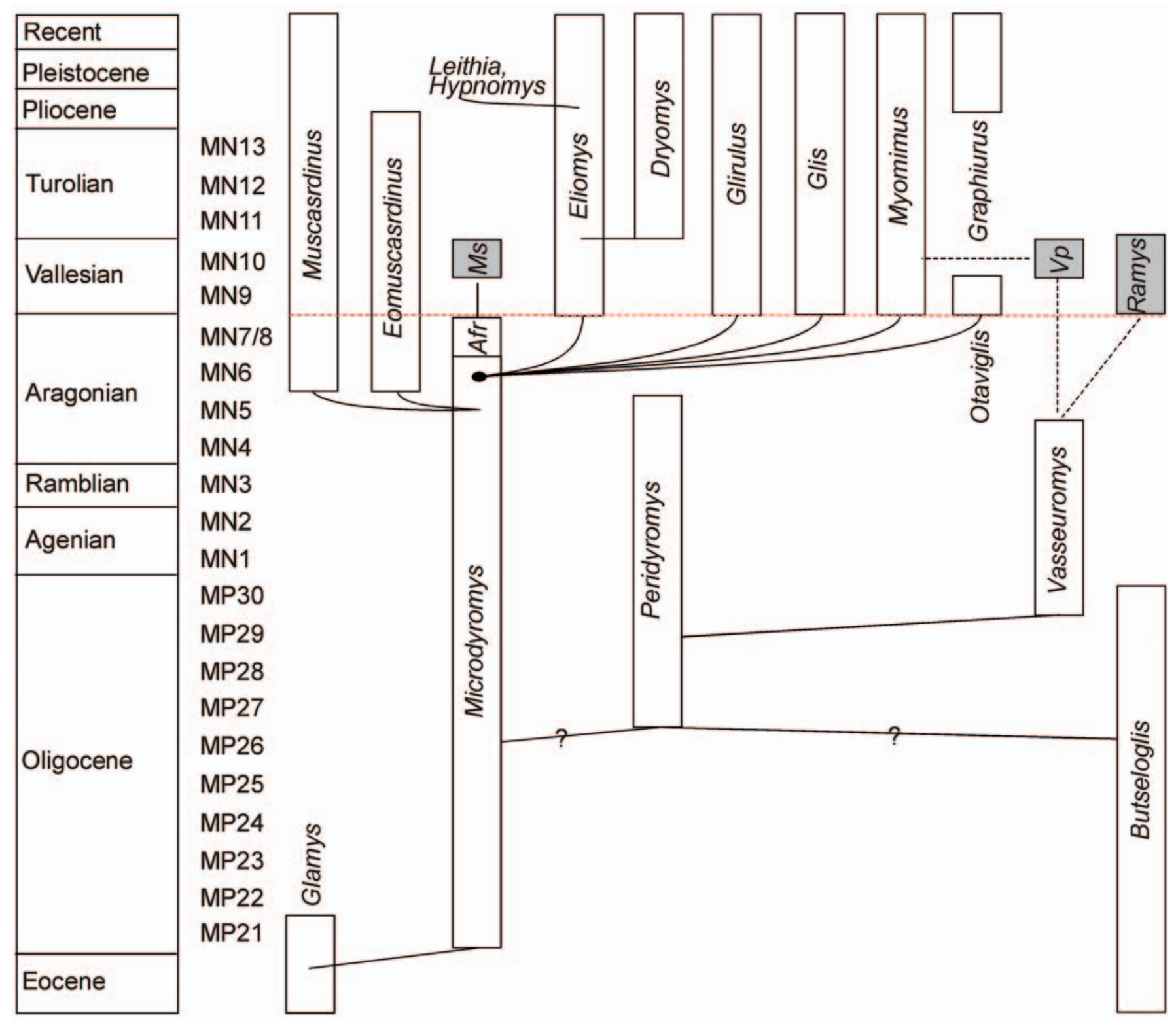

Figure 2. Proposed phylogeny of extant Gliridae. Grey fields are records for which the phylogeny is uncertain.

We think, however, that that fauna is a mixture of various ages and that the genus does not appear before MN6 (see Fig. 2).

García-Alix et al. (2008a) distinguished two lineages within Muscardinus:

M. thaleri (MN6)-hispanicus-pliocaenicus-avellanarius (Recent) and M. sansaniensis (MN6)-vallesiensis-viretimeridionalis-helleri (MN15). The first lineage contains the oldest record of modern glirids, but we are not sure that it is derived from M. sansaniensis. The second one may be a lineage of "old" glirids (with caecum) and in that case the genus name Eomuscardinus Hartenberger, 1967 is available. Whether or not Eomuscardinus is considered a separate genus is not decided here. It depends on the question whether it had a caecum or not, and that cannot be resolved. The coexistence of two species in Can Llobateres may be an indication in favour of separating them.

Subfamily Dryomyinae de Bruijn, 1967

Genus Dryomys Thomas, 1906

According to Daams \& de Bruijn (1995) the oldest occurrence in Europe of Dryomys may be that of Dryomys sp. from the Late Miocene (MN11) of Dorn-Dürkheim (Franzen \& Storch, 1975), but it is essentially restricted to the Pleistocene and Holocene. Dryomys ambiguus from MN7/8 of Beni Mellall was placed in Dryomys by Lavocat (1961). Jaeger (1977a) placed it in Microdyromys and Jaeger (1977b) created the new genus Afrodyromys for it. Afrodyromys was considered a synonym of Dryomys by 
Daams (1981). Whether or not Afrodyromys deserves to be considered a separate genus is not clear, but its taxonomic history may well be an indication of the ancestral position of Microdyromys with respect to Dryomys.

\section{Genus Eliomys Wagner, 1840}

The oldest records of Eliomys are E. assimilis and E. reductus from the Late Miocene of Hammerschmiede (MN9, Germany). Several species, e.g., E. truci Mein \& Michaux, 1970 are recorded from the Late MiocenePliocene (MN12-16, García-Alix et al., 2008b) of France and Spain. It is not clear why they are attributed to Eliomys, and not to Dryomys, and one of these species might be the ancestor of Dryomys apulus Freudenthal \& Martín Suárez, 2006. Eliomys is considered to be the origin of Dryomys and of a number of Plio-Pleistocene genera from Mediterranean islands, like Hypnomys Bate, 1918, Leithia Lydekker, 1896, etc. Hypnomys was placed in synonymy with Eliomys by Bover \& Alcover (2008).

\section{Genus Glirulus Thomas, 1906}

Glirulus conjunctus (Mayr, 1979) from Marktl (MN9) was originally described as Paraglirulus Engesser, 1972. Daams \& de Bruijn (1995) placed it in Glirulus. If that is correct it is the oldest record of Glirulus after the gap between MN4 and MN9.

Older records of Glirulus range between $G$. aff. ekremi from Harami 1 (MN2; Ünay, 1994) and G. daamsi from Çandir (MN5/6?; de Bruijn et al., 2003).

According to Daams \& de Bruijn (1995) Paraglirulus contains two species: the type species $P$. werenfelsi Engesser, 1972 from Anwil (MN7/8) and P. agelakisi van der Meulen \& de Bruijn, 1982 from Aliveri (MN4A). For the moment the Glirulus records from MN2 to MN5/6 may be placed in Paraglirulus: P. diremptus Mayr, 1979; G. daamsi de Bruijn et al., 2003; G. ekremi Ünay, 1994 and G. minor $\mathrm{Wu}, 1993$. In Figure 1 they form the unnamed subfamily 4 .

\section{Subfamily Myomyinae Daams, 1981}

Genus Myomimus Ognev, 1924

The oldest record of Myomimus is Myomimus sp. from Keseköy (MN3, Ünay, 1994). De Bruijn et al. (2003) postulated the synonymy of Myomimus and Peridyromys, as already suggested by de Bruijn et al. (1970). The oldest record of Peridyromys is P. murinus Pomel, 1853 from Mirambueno 1 (MP27, Freudenthal, 1997); the youngest record is $P$. sondaari from Vargas 2A (MN5, Daams, 1999). Neither Myomimus nor Peridyromys are recorded in MN6 through MN8 (the dating of Çandir as MN6 is questionable; see de Bruijn et al., 2003), and true
Myomimus appears in MN9: Myomimus dehmi (de Bruijn, 1966b). In the concept proposed here the records from MN5 and older should be placed in Peridyromys, and those from MN9 and younger in Myomimus.

If one wishes to maintain the subfamily Myomiminae it should be restricted to Myomimus, and the other genera previously placed in Myomiminae form a new subfamily, Peridyromyinae (Number 3 in Fig. 1):

\section{Subfamily Peridyromyinae subfamilia nov.}

Type-genus. Peridyromys Stehlin \& Schaub, 1951

Diagnosis. Daams (1981) gave the following diagnosis for the Myomiminae: "Concave occlusal surface, main cusps fairly well developed, extra ridges narrower than main ridges, relatively high-crowned molars in some genera, generally no endoloph in the M1,2 and a simple dental pattern."

This is in fact the diagnosis of Peridyromyinae, and if one wishes to maintain the subfamily Myomiminae a much more restricted diagnosis can be made.

Genera included. Peridyromys; Altomiramys DíazMolina \& López-Martínez, 1979; Armantomys; Miodyromys Kretzoi, 1943; Praearmantomys de Bruijn, 1966a; Pseudodryomys de Bruijn, 1966a; Simplomys GarcíaParedes et al., 2009; Tempestia van de Weerd, 1976; Ramys García Moreno \& López Martínez, 1986 and Vasseuromys Baudelot \& de Bonis, 1966.

Of these Vasseuromys and Ramys do not fit the diagnosis, especially with respect to the simple dental pattern. Their inclusion in Peridyromyinae is provisional and based on the supposed origin in Peridyromys.

Daams \& de Bruijn (1995) thought Peridyromys to be derived from Gliravus s.l.; since then the genus Gliravus has been split in Gliravus, Glamys and Butseloglis (=Schizogliravus Freudenthal, 2004). The type-species of Gliravus and two closely related species are restricted to MP24; five other species are attributed to Gliravus, simply because no action was taken when Glamys and Butseloglis were split off. They all are from the Eocene (MP17) and this discontinuous distribution may mean that Gliravus in its present concept is heterogeneous. Some of these five species may be placed in Glamys (G. robiacensis Hartenberger, 1971), but others not (G. meridionalis from Sossís 1, figured by Agustí \& Arcas, 1997) (see Freudenthal, 2004).

This makes Butseloglis a possible ancestor of Peridyromys in view of its stratigraphic distribution (and in agreement with Daams \& de Bruijn (1995), since Butseloglis is part of their Gliravus s.1.). However, Microdyromys cannot be ruled out as a possible ancestor (see Fig. 2). 

1996

Subfamily Graphiurinae Vianey-Liaud \& Jaeger,

Genus Graphiurus Smuts, 1832

Vianey-Liaud \& Jaeger (1996) created the family Graphiuridae for the extant African genus Graphiurus on the basis of its hystricomorphous skull. The oldest record of Graphiurus is Graphiurus sp. from the Pliocene of Langebaanweg (Pocock, 1976). According to Mein et al. (2000) Graphiurus may be a descendent of Otaviglis Mein et al., 2000 from MN9 of Harasib, and these authors think that Otaviglis may be a descendent of Microdyromys. We think that the oval shape of the upper premolar, typical for Bransatoglirinae, and the broad lower molars, strengthen this point.

\section{MOLECULAR SYSTEMATICS}

Montgelard et al. (2003) gave ages for the origin of the modern genera on the basis of molecular distance and observed that the calculated origins are much older than the appearance in the fossil record. Similar results were obtained by Nunome et al. (2007). Their calculations are based on a supposed base age of 50 My (Eocene MP10, the age of the oldest known glirid, Eogliravus wildi). We recalculated their results, multiplying them by 0.33 , for a base age of $16 \mathrm{My}$, which we postulate as the age at which glirids still had the caecum (see Table 3). In Figure 1 , the ages by Montgelard et al. (2003) are indicated by circles and our recalculated ages by asterisks. The FAD's of the extant genera, except Graphiurus, give a remarkably good fit with the latter calculations. The first occurrence of Graphiurus is Graphiurus sp. from the Pliocene of Langebaanweg (Pocock, 1976), dated at 5 My ago, which is 11 My younger than the recalculated age (see Fig. 2). Otaviglis Mein, Pickford \& Senut, 2000, the ancestor of

Table 3. Divergence times of recent Gliridae from Montgelard et al. (2003) and recalculated ages for a base age of 16 My, compared with the oldest known records.

\begin{tabular}{llllll}
\hline & \multicolumn{1}{c}{ My } & MN & \multicolumn{1}{c}{ My } & \multicolumn{1}{c}{ MN } & FAD \\
\hline base age & 50 My & & 16 My & & \\
Glirulus & 27.7 & MP27 & 9.2 & MN10 & MN9 \\
Glis & 27.7 & MP27 & 9.2 & MN10 & MN9 \\
Dryomys & 28.5 & MP26 & 9.5 & MN9/10 & MN11 \\
Eliomys & 28.5 & MP26 & 9.5 & MN9/10 & MN9 \\
Myomimus & 38.1 & MP16 & 12.7 & MN7 & MN9 \\
Muscardinus & 40.8 & MP15 & 13.6 & MN6 & MN6 \\
Graphiurus & 50.0 & MP10 & 16.0 & MN4 & Pliocene \\
Otaviglis & & & & & MN9 \\
\hline
\end{tabular}

Graphiurus, is reported to have an age of 10-11 My, which is still 5 My younger (see Montgelard et al., 2003).

\section{DISCUSSION}

Wahlert et al. (1993) grouped living glirids, on the basis of cranial, mandibular, and dental morphology, in two subfamilies: their Leithiinae (=Dryomyinae) and Myoxinae (=Glirinae). Leithiinae consists of two tribes, the Leithiini (Eliomys and Dryomys) and the Myomimini (Myomimus and Selevinia). Myoxinae includes Myoxus (=Glis), Glirulus and Muscardinus.

Storch (1995) placed Myomimus in Seleviniinae (=Myomiminae), Eliomys and Dryomys in Dryomiinae and Myoxus (=Glis), Glirulus and Muscardinus in Glirinae. Characters used are the dental occlusal pattern, skull, enamel ultrastructure of the lower incisors, muscles of mastication, external male genital morphology, and auditory region.

Among living glirids Daams \& de Bruijn (1995) recognized the subfamilies Glirinae, Myomiminae and Dryomyinae and they included several extinct subfamilies. At present this classification, based exclusively on dental morphology is widely accepted. Basically these three classifications are the same, though the actual names and the taxonomic level may be different. The similarities in the dental pattern led Daams \& de Bruijn to classify a number of fossil species in recent genera.

We consider these similarities to be convergencies. The almost complete absence of the modern genera in MN6-8, the simultaneous (re)appearance of the modern genera and the absence of the caecum are arguments for a fundamentally different concept of the systematics of Gliridae.

Gliridae reached their maximum species diversity in the Early Miocene, and at that time they often were the dominant family, with up to $90 \%$ of the rodent specimens. This diversity and the presence of hypsodont forms make us suppose that until MN5 they still had a caecum. It is highly unlikely that the loss of the caecum happened independently in all lineages of extant glirids, so we hypothesize that they are derived from one single taxon without caecum, not older than MN5 (around 15/16 My ago). Diversification starts in MN6 with the appearance of Muscardinus, whereas the other modern genera appear in MN9 (between 11 and $10 \mathrm{My}$ ago). That makes the usefulness of the subfamily names Myomiminae and Dryomyinae questionable; one subfamily, Glirinae, is sufficient to house the extant genera and several genera from Mediterranean Late Miocene to Pleistocene island faunas, like Stertomys Daams \& Freudenthal, 1985 and Leithia. There is, however, no argument against maintaining them as separate subfamilies, or reducing them to tribe rank. In any case, in this concept, they no longer 
include the records from the Middle Miocene and older that were previously classified in Glirinae (Glis, Heteromyoxus, Glirudinus and Myoglis) or in Dryomyinae (Glirulus and Paraglirulus), and Myomiminae is reduced to the typegenus only. The hystricomorph condition is an argument to maintain the subfamily Graphiurinae.

Among the fossil glirids the subfamilies Bransatoglirinae (Bransatoglis Hugueney, 1967, Oligodyromys Bahlo, 1975, Paraglis Werner, 1994 and Microdyromys), Gliravinae (Gliravus, Eogliravus Hartenberger, 1971 and Butseloglis) and Glamyinae (Glamys) remain unchanged.

The subfamily Myomiminae is restricted to Myomimus, and a new subfamily, Peridyromyinae, type-genus Peridyromys, is created to house the genera from MN5 or older that were previously assigned to Myomiminae.

Ramys (MN9-10) may be a Peridyromyinae, related to Vasseuromys (Agustí et al., 2011), but it may also be related to the modern Myomimus lineage that starts in MN9. Neither can we be sure about Microdyromys sinuosus, a reappearance of the genus in MN10 after its extinction in MN6, and a similar case is Vasseuromys pannonicus Kretzoi, 1980 from MN10. These doubtful cases are indicated as shaded fields in Fig. 2.

One of the most remarkable facts is the moment of first appearance of the modern Gliridae. Muscardinus appears in MN6 and is regarded to be the first of the modern glirids. Its derived dental pattern, however, excludes it as a possible ancestor of the other genera.

The first occurrence of Graphiurus is Graphiurus sp. from the Pliocene of Langebaanweg (Pocock, 1976), dated at $5 \mathrm{My}$ ago and Dryomys appears in MN11, probably as an off-shoot from Eliomys. The other extant Gliridae appear simultaneously in the Early Vallesian, MN9, including Otaviglis, which is the ancestor of Graphiurus. The time gap between Otaviglis and Graphiurus is probably due to lack of data.

We think the origin of all extant glirids is a Microdyromys from MN5/6, which had lost the caecum. Other possibilities cannot be excluded, but Microdyromys has the least derived dental pattern. The radiation of Eliomys, Glirulus, Glis, Myomimus and Graphiurus took place shortly before the beginning of the Vallesian (see Fig. 2).

The loss of the caecum appears to be a negative factor because it puts limits to the ecological possibilities of the glirids and for that reason alone it is unlikely that it would have happened several times in different lineages. In fact it is an exceptional phenomenon that offers no evident advantages; otherwise it certainly would have occurred in some of the other 2,250 rodent species, and that has not been observed. An unresolved question is, why the "better equipped" ancient glirids became extinct around MN9, at the same time that the modern glirids, with an apparent disadvantage, began to flourish.
We are well aware that our new concept is quite unorthodox, and impossible to prove with hard paleontological material, but we did not find any other plausible explanation. In fact, the question is whether the loss of the caecum is the result of the glirid diet or the cause of it. We think the latter is the most probable because it requires only one event. Its logical consequence is the taxonomy presented here.

\section{CONCLUSIONS}

The current classification implies that the loss of the caecum would have taken place independently in a number of already separated subfamilies. We find that improbable and propose a monophyletic phylogeny, starting about 15/16 million years ago. This hypothesis means that:

All extant Gliridae are derived from one single Middle Miocene species, probably a Microdyromys.

The occurrences of Glis and Glirulus from MN5 and older belong to other genera. Peridyromys is a separate genus and not a synonym of Myomimus.

Muscardinus is the only modern glirid in the Middle Miocene; the other genera appear simultaneously in the Early Vallesian.

The divergence data based on molecular systematics and a base age of $50 \mathrm{My}$, calculated by Montgelard et al. (2003) show strong discrepancies with the fossil record. Recalculation for a base age of 16 My gives a remarkable good fit with the FAD of the recent taxons.

The loss of the caecum is an exceptional phenomenon that offers no evident advantages, and did not occur in any other rodent group. We have no explanation for the fact that the ancient Gliridae became extinct simultaneously with the radiation of the modern genera.

\section{ACKNOWLEDGEMENTS}

Thanks are due to Drs H. de Bruijn, P. Mein and F.J. Ruiz-Sánchez for critically reading the manuscript. Two anonymous referees and the editor of Paleontologia Electronica helped to improve the text. This study was carried out in the framework of the program "Huellas isotópicas en micromamíferos fósiles como indicadores del cambio climático (RNM 8011)" of the "Junta de Andalucía". 


\section{REFERENCES}

Aguilar, J.P. 1974. Les Rongeurs du Miocène inférieur en Bas-Languedoc et les corrélations entre échelles stratigraphiques marine et continentale. Géobios, 7, 4, 345-398.

Aguilar, J.P. \& Lazzari, V. 2006. Nouvelles espèces de gliridés du gisement karstique de Blanquatère 1 (Miocène moyen, sud de la France). Geodiversitas, 28, 277-295.

Agustí, J. 1981. Glis vallesiensis n. sp. Nouveau Gliride (Rodentia, Mammalia) du Néogène de Seu d'Urgell (Catalogne, Espagne). Géobios, 14, 4, 543-547.

Agustí, J. \& Arbiol, S. 1989. Nouvelles espèces de rongeurs (Mammalia) dans l'Oligocène supérieur du Bassin de l'Ebre (N.E. de l'Espagne). Géobios, 22, 3, 265-275.

Agustí, J. \& Arcas, A. 1997. Gliridae (Mammalia, Rodentia) from the Late Eocene of Sossis. Münchner Geowissenschaftliche Abhandlungen, A, Geologie Paleontologie, 34, 23-32.

Agustí, J., Pérez-Rivarés, F.J., Cabrera, L., Garcés, M., Pardo, G. \& Arenas, C. 2011. The Ramblian-Aragonian boundary and its significance for the European Neogene continental chronology. Contributions from the Ebro Basin record (NE Spain). Géobios, 44, 121-134.

Alvarez Sierra, M.A. 1986. In: Alvarez Sierra, M.A. \& E. García Moreno, 1986. New Gliridae and Cricetidae from the Middle and Upper Miocene of the Duero Basin, Spain. Stvdia Geologica Salmanticensia, 22, 145-189.

Bahlo, E. 1975. Die Nagetierfauna von Heimersheim bei Alzey (Rheinhessen, Westdeutschland) aus dem Grenzbereich Mittel/Oberoligozän und ihre stratigrafische Stellung. Abhandlungen Hessisches Landesamt für Bodenforschung, 71, 1-182.

Bate, D.M.A. 1918. On a new genus of extinct Muscardine Rodent from the Balearic Islands. Proceedings Zoological Society London, 209-222.

Baudelot, S. 1965. Complément à l'étude de la faune des rongeurs de Sansan: les Gliridés. Bulletin Société Géologique France, 7, 8, 758-764.

Baudelot, S. \& de Bonis, L. 1966. Nouveaux Gliridés (Rodentia) de l'Aquitanien du Bassin d'Aquitainie. Comptes Rendus sommaires Société Géologique de France, 1966, 9, 341-342.

Biochrom'97 1997. Syntheses and correlation tables. In: Actes du Congrès BiochroM'97 (eds. Aguilar, J.P., Legendre, S. \& Michaux, J.), Mémoires Travaux E.P.H.E., Institut Montpellier, 21, 337-352.

Bosma, A. \& de Bruijn, H. 1982. Eocene and Oligocene Gliridae (Rodentia, Mammalia) from the Isle of Wight, England. Part II. Gliravus minor n.sp., Gliravus daamsi n.sp., Bransatoglis bahloi n.sp. Proceedings Koninklijke Nederlandse Akademie van Wetenschappen, B, 85, 4, 365-380.

Bover, P. \& Alcover, J.A. 2008. Extinction of the autochthonous small mammals of Mallorca (Gymnesic Islands, Western Mediterranean) and its ecological consequences. Journal of Biogeography, 35, 1112-1122.
Brisson, A.D. 1762. Regnum Animale in Classes IX. Distributum, sive Synopsis Methodica. T. Haak, Leiden, 1-296.

Bruijn, H. de 1966a. Some new Miocene Gliridae (Rodentia, Mammalia) from the Calatayud Area (prov. Zaragoza, Spain). Proceedings Koninklijke Nederlandse Akademie van Wetenschappen, $B, 69,1,1-21$.

Bruijn, H. de 1966b. On the Mammalian fauna of the Hipparion-Beds in the Calatayud-Teruel Basin (prov. Zaragoza, Spain). Part II. The Gliridae (Rodentia). Proceedings Koninklijke Nederlandse Akademie van Wetenschappen, B, 69, 58-78.

Bruijn, H. de 1967. Gliridae, Sciuridae y Eomyidae (Rodentia, Mammalia) miocenos de Calatayud (provincia de Zaragoza, España) y su relación con la bioestratigrafía del área. Boletín Instituto Geológico Minero España, 78, 187-373.

Bruijn, H. de, Daams, R., Daxner-Höck, G., Fahlbusch, V., Ginsburg, L., Mein, P. \& Morales, J. 1992. Report of the RCMNS working group on fossil mammals, Reisenburg 1990. Newsletters on Stratigraphy, 26, 2-3, 65-118.

Bruijn, H. de, Dawson, M.R. \& Mein, P. 1970. Upper Pliocene Rodentia, Lagomorpha and Insectivora (Mammalia) from the Isle of Rhodes (Greece). Proceedings Koninklijke Nederlandse Akademie van Wetenschappen, B, 73, 5, 535-584.

Bruijn, H. de, van den Hoek Ostende, L., Kristkoiz-Boon, E., Rummel, M., Theocharopoulos, C. \& Ünay, E. 2003. Rodents, lagomorphs and insectivores from the middle Miocene hominoid locality of Çandir (Turkey). Courier Forschungs-Institut Senckenberg, 240, 51-87.

Bruijn, H. de \& Rümke, C. 1974. On a peculiar mammalian association from the Miocene of Oschiri (Sardinia). Proceedings Koninklijke Nederlandse Akademie van Wetenschappen, B, 77, 1, 45-79.

Daams, R. 1976. Miocene Rodents (Mammalia) from Cetina de Aragón (Prov. Zaragoza) and Buñol (Prov. Valencia), Spain. Proceedings Koninklijke Nederlandse Akademie van Wetenschappen, $B, 79,3,152-182$.

Daams, R. 1981. The dental pattern of the dormice Dryomys, Myomimus, Microdyromys and Peridyromys. Utrecht Micropaleontological Bulletins, Special Publication, 3, $1-115$.

Daams, R. 1985. Glirinae (Gliridae, Rodentia) from the type area of the Aragonian and adjacent areas (provinces of Teruel and Zaragoza, Spain). Scripta Geologica, 77, $1-20$.

Daams, R. 1990. Hypsodont Myomiminae (Gliridae, Rodentia) from the Miocene and the Oligocene-Miocene boundary interval of Spain. Scripta Geologica, 95, 1-63.

Daams, R. 1999. Peridyromys darocensis and Peridyromys sondaari, two new species of Gliridae (Rodentia, Mammalia) from the Lower Miocene (MN3-5) of the Calatayud-Daroca Basin, Zaragoza, Spain. Deinsea, 7, 83-90.

Daams, R. \& de Bruijn, H. 1995. A classification of the Gliridae (Rodentia) on the basis of dental morphology. Hystrix, 6, 1-2, 3-50. 
Daams, R. \& M. Freudenthal, 1985. Stertomys laticrestatus, a new glirid (dormice, Rodentia) from the insular fauna of Gargano (Prov. of Foggia, Italy). Scripta Geologica, $77,21-27$.

Daams, R., Freudenthal, M., Lacomba, J.I. \& Alvarez, M.A. 1989. Upper Oligocene micromammals from Pareja, Loranca Basin, prov. of Guadalajara, Spain. Scripta Geologica, 89, 27-56.

Daams, R. \& van der Meulen, A.J. 1984. Paleoenvironmental and paleoclimatic interpretation of micromammal faunal successions in the Upper Oligocene and Miocene of north central Spain. Paléobiologie Continentale, 14, 2, 241-257.

Dehm, R. 1935. Über tertiäre Spaltenfüllungen im Fränkischen und Schwäbischen Jura. Abhandlungen Bayerische Akademie Wissenschaften, math. nat. Abt., 29, 1-86.

Dehm, R. 1938. Heteromyoxus n.g. und Dryomys Thomas, zwei Schlafmäuse im Untermiocän (Aquitanium) von Ulm. Zentralblatt Mineralogie, B, 9, 2, 337-343.

Díaz Molina, M. \& López Martínez, N. 1979. El Terciario continental de la Depresión Intermedia (Cuenca). Bioestratigrafía y Paleogeografía. Estudios Geológicos, 35, 149-167.

Dominguez-Bello, M.G. \& Robinson, M.D. 1991. A comparison of digestive adaptation in two neotropical cricetid rodents (Holochilus venezuelae and Zygodontomys microtinus). Physiological Zoology, 64, 1542-1551.

Engesser, B. 1972. Die obermiozäne Säugetierfauna von Anwil (Baselland). Tätigkeitsberichte Naturforschenden Gesellschaft Baselland, 28, 35-363.

Franzen, J. L. \& Storch, G. 1975. Die unterpliozäne (turolische) Wirbeltierfauna von Dorn-Dürkheim, Rheinhessen (SWDeutschland). 1. Entdeckung, Geologie, Mammalia: Carnivora, Proboscidea, Rodentia. Senckenbergiana Lethaea, 56, 4-5, 233-303.

Freudenthal, M. 1996. The Early Oligocene rodent fauna of Olalla 4A (Teruel, Spain). Scripta Geologica, 112, 1-67.

Freudenthal, M. 1997. Paleogene rodent faunas from the province of Teruel (Spain). In: Actes du Congrès BiochroM'97 (eds. Aguilar, J.P., Legendre, S. \& Michaux, J.), Mémoires Travaux E.P.H.E., Institut Montpellier, 21, 397-415.

Freudenthal, M. 2004. Gliridae (Rodentia, Mammalia) from the Eocene and Oligocene of the Sierra Palomera (Teruel, Spain). Treballs del Museu de Geologia de Barcelona, 12, 97-173.

Freudenthal, M. \& Martín-Suárez, E. 2006. Gliridae (Rodentia, Mammalia) from the late Miocene fissure filling Biancone 1 (Gargano, province of Foggia, Italy). Palaeontologia Electronica, 9, 2, 1-23.

Freudenthal, M. \& Martín-Suárez, E. 2007a. Microdyromys (Gliridae, Rodentia, Mammalia) from the Early Oligocene of Montalbán (Prov. Teruel, Spain). Scripta Geologica, 135, 179-211.

Freudenthal, M. \& Martín-Suárez, E. 2007b. Revision of the subfamily Bransatoglirinae (Gliridae, Rodentia, Mammalia). Scripta Geologica, 135, 241-273.
García-Alix, A., Minwer-Barakat, R., Martín-Suárez, E. \& Freudenthal, M. 2008a. Muscardinus meridionalis sp. nov., a new species of Gliridae (Rodentia, Mammalia) and its implications for the phylogeny of Muscardinus. Journal of Vertebrate Paleontology, 28, 2, 568-573.

García-Alix, A., Minwer-Barakat, R., Martín-Suárez, E. \& Freudenthal, M. 2008b. Cricetidae and Gliridae (Rodentia, Mammalia) from the Miocene and Pliocene of southern Spain. Scripta Geologica, 136, 1-37.

García Moreno, E. 1986. El género Megacricetodon (Cricetidae, Rodentia) en el Aragoniense y Vallesiense de la Cuenca del Duero. Relaciones filogenéticas. COL-PA, 41, 51-106.

García Moreno, E. \& López Martínez, N. 1986. Ramys, a new genus of Gliridae (Rodentia) from the Lower Vallesian of Spain. Proceedings Koninklijke Nederlandse Akademie van Wetenschappen, B, 89, 4, 337-355.

García-Paredes, I., Peláez-Campomanes, P. \& Alvarez Sierra, M.A. 2009. Gliridae (Rodentia, Mammalia) with a simple dental pattern: a new genus and new species from the European Early and Middle Miocene. Zoological Journal of the Linnean Society, 157, 622-652.

Hartenberger, J.L. 1967. Les rongeurs du Vallésien (Miocène supérieur) de Can Llobateres (Sabadell, Espagne): Gliridae et Eomyidae. Bulletin de la Société Géologique de France, 7, 8, 596-604.

Hartenberger, J.L. 1971. Contribution à l'étude des genres Gliravus et Microparamys (Rodentia) de l'Eocène d'Europe. Palaeovertebrata, 4, 97-135.

Hugueney, M.1967. Les Gliridés (Mammalia, Rodentia) de l'Oligocène supérieur de Coderet-Branssat (Allier). Comptes Rendus sommaires Société Géologique de France, 1967, 3, 91-92.

Hugueney, M. \& Adrover, R. 1990. Rongeurs (Rodentia, Mammalia) de l'Oligocène de Sineu (Baleares, Espagne). Paleontologia i Evolució, 23, 157-169.

Jaeger, J.J. 1977a. Rongeurs (Mammalia, Rodentia) du Miocène de Beni Mellal. Palaeovertebrata, 7, 4, 91-125.

Jaeger, J.J. 1977b. Les rongeurs du Miocène moyen et supérieur du Maghreb. Palaeovertebrata, 8, 1, 1-166.

Kaiser, T.M., Müller, D.W.H., Fortelius, M., Schulz, E., Codron, D. \& Clauss, M. 2011. Hypsodonty and tooth facet development in relation to diet and habitat in herbivorous ungulates: implications for understanding tooth wear. Mammal Review. doi: 10.1111/j.1365-2907.2011.00203.x.

Kaup, J. 1829. Skizzierte Entwicklungs-Geschichte und Natürliches System der Europäischen Thierwelt. C.W. Leske, Darmstadt/Leipzig, 1, 1-203.

Kretzoi M. 1943. Ein neuer Muscardinide aus dem Ungarischen Miozän. KüIönlenyomat a Földtani Közlöny, 73, 1-3, 271- 273.

Kretzoi, M. 1980. Wichtigere Streufunde in der wirbeltierpaläontologischen Sammlung der Ungarischen Geologischen Anstalt.1. Wirbeltierfauna des pliozänen Süßwasserkalkes am Széchenyi-Berg in den Budaer Bergen. Magyar Allami Földtami Intézet Évi Jelentése, 1978, 347-358. 
Lacomba, J.I. \& Martínez-Salanova, J. 1988. Quercomys bijmai gen. nov. sp. nov. (Gliridae, Rodentia, Mammalia) del tránsito Oligoceno-Mioceno Español. Estudios Geológicos, 44, 107-118.

Lartet, E., 1851 Notice sur la colline de Sansan. Portes, Auch, 1-47

Lavocat, R. 1961. Le gisement de vertébrés miocènes de Beni Mellal (Maroc). Etude systématique de la faune de mammifères et conclusions générales. Notes Mémoires Service Géologique Maroc, 155, 1-145.

Lourens, L.J., Hilgen, F.J., Shackleton, N.J., Laskar, J. \& Wilson, D.S. 2004. The Neogene period. In: A Geologic Time Scale 2004 (eds. Gradstein F.N., Ogg, J.G. \& Smith, A.G.). Cambridge University Press, 409-440.

Lydekker, R. 1896. On the Affinities of the so-called Extinct Giant Dormouse of Malta. Proceedings Zoological Society London, 1895, 860-863.

Mayr, H. 1979. Gebissmorphologische Untersuchungen an miozänen Gliriden (Mammalia, Rodentia) Süddeutschlands. PhD Thesis, University Munich.

Mein, P. \& Michaux, J.J. 1970. Un nouveau stade dans l'évolution des rongeurs pliocènes de l'Europe sudoccidentale. Comptes rendus Académie des Sciences Paris, D, 270, 2780-2783.

Mein, P., Pickford, M. \& Senut, B. 2000. Late Miocene micromammals from the Harasib karst deposits, Namibia. Part 1. Large muroids and non-muroid rodents. Communications of the Geological Survey of Namibia, 12, 375-390.

Meulen, A.J. van der \& de Bruijn, H. 1982. The mammals from the Lower Miocene of Aliveri (Island of Evia, Greece). Part 2: The Gliridae. Proceedings Koninklijke Nederlandse Akademie van Wetenschappen, B, 85, 4, 485-524.

Montgelard, C., Matthee, C.A. \& Robinson, T.J. 2003. Molecular systematics of dormice (Rodentia: Gliridae) and the radiation of Graphiurus in Africa. Proceedings Royal Society London, B, 270, 1947-1955.

Muirhead, L. 1819. Mazology. In: The Edinburgh Encyclopedia (ed. Brewster, D.). W. Blackwood, Edinburgh, 13, 393486.

Nemetschek, A. \& Mörs, T. 2003. Myoglis meini (de Bruijn, 1965 [1966]) (Mammalia: Gliridae) aus dem Miozän von Hambach 6C (NW-Deutschland). Paläontologische Zeitschrift, 77, 401-416.

Nunome, M., Yasuda, S.P., Sato, J.J., Vogel, P. \& Suzuki, H. 2007. Phylogenetic relationships and divergence times among dormice (Rodentia, Gliridae) based on three nuclear genes. Zoologica Scripta, 36, 6, 537-546.

Ognev S.I. 1924. Nature and sport in Ukraine. Kharkov, 1 p.

Pocock, T.N. 1976. Pliocene mammalian microfauna from Langebaanweg: a new fossil genus linking the Otomyinae with the Murinae. South African Journal of Science, 72, 58-60.

Pomel, A. 1853. Catalogue méthodique et descriptif des vertébrés fossiles découverts dans le bassin hydrographique supérieur de la Loire et surtout dans la vallée de son affluent principal, l'Allier. J.B. Baillière, Paris, 1-193.
Rabeder, G. 1984. Bransatoglis (Gliridae, Rodentia, Mammalia) aus dem Mittelmiozän von Schönweg bei St. Andrä im Lavanttal (Kärnten) Beiträge Paläontologie Österreich, 11, 511-519.

Ruiz-Sánchez, F.J., Murelaga, X., Freudenthal, M., Larrasoaña, J.C. \& Garcés, M. 2012. A new species of glirid rodent Vasseuromys from the Aragonian (Miocene) of the Ebro Basin (north-eastern Spain). Acta Palaeontologica Polonica, 57, 2, 225-239.

Ruiz-Sánchez, F.J., Lacomba-Andueza, J.I, Freudenthal, M. \& Álvarez-Sierra, M.Á. (in prep). A new species of Vasseuromys (Gliridae, Mammalia) from the Upper Oligocene of the Ebro Basin (Spain). Paläontologische Zeitschrift.

Smuts, J. 1832. Enumerationem mammalium Capensium. J.C. Cyfveer, Leiden, 1-105.

Stehlin, H.G. \& Schaub, S. 1951. Die Trigonodontie der simplicidentaten Nager. Schweizerische Paläontologische Abhandlungen, 67, 1-385.

Storch, G. 1995. Affinities among living dormouse genera. Hystrix (n.s.), 6, 1-2, 51-62.

Storch, G. \& Seiffert, C. 2007. Extraordinarily preserved specimen of the oldest known glirid from the middle Eocene of Messel (Rodentia). Journal of Vertebrate Paleontology, 27, 1, 189-194.

Thomas O. 1906. The Duke of Bedford's zoological exploration in eastern Asia. 1. List of mammals obtained by Mr. M.P. Anderson in Japan. Proceedings Zoological Society London, 1905, 2, 331-363.

Tullberg, T. 1899. Ueber das System der Nagethiere. Eine phylogenetische Studie. Nova Acta Regalis Societatis Scienciarum Upsaliensis, 3, 1-514.

Ünay-Bayraktar, E. 1989. Rodents from the middle Oligocene of Turkish Thrace. Utrecht Micropaleontological Bulletins, $5,1-119$.

Ünay, E. 1994. Early Miocene rodent faunas from the eastern Mediterranean area. Part IV. The Gliridae. Proceedings Koninklijke Nederlandse Akademie van Wetenschappen, 97, 4, 445-490.

Vianey-Liaud, M. 1989. Parallelism among Gliridae (Rodentia): the genus Gliravus Stehlin \& Schaub. Historical Biology, 2, 213-226.

Vianey-Liaud, M. 1994. La radiation des Gliridae (Rodentia) à l'Eocène supérieur en Europe Occidentale et sa descendance Oligocène. Münchner Geowissenschaftliche Abhandlungen, A, 26, 117-160.

Vianey-Liaud, M. 2004. Gliridae (Mammalia, Rodentia) de l'Oligocène européen origine de trois genres miocènes. Coloquios de Paleontología, Volumen Extraordinario, 1, 669-698.

Vianey-Liaud, M. \& Jaeger, J.J. 1996. A new hypothesis for the origin of African Anomaluridae and Graphiuridae (Rodentia). Palaeovertebrata, 25, 349-358.

Wagner, J.A. 1840. Beschreibung einiger neuer Nager. Abhandlungen mathematisch-physische Classe, Koenigliche Bayerische Akademie Wissenschaften München, 3, 173-218. 
Wahlert, J.H., Sawitzke, S.L. \& Holden, M.E. 1993. Cranial Anatomy and Relationships of Dormice (Rodentia, Myoxidae). American Museum Novitates, 3061, 1-32.

Weerd, A. van de 1976. Rodent faunas of the Mio-Pliocene continental sediments of the Teruel-Alfambra region, Spain. Utrecht Micropaleontological Bulletins, spec. publ., 2, 1-217.

Werner, J. 1994. Beiträge zur Biostratigraphie der Untern Süsswasser-Molasse Süddeutschlands - Rodentia und
Lagomorpha (Mammalia) aus den Fundstellen der Ulmer Gegend. Stuttgarter Beiträge Naturkunde, B, 200, 1-263.

Wu, W. 1993. Neue Gliridae (Rodentia, Mammalia) aus untermiozänen (orleanischen) Spaltenfüllungen Süddeutschlands. Documenta Naturae, 81, 1-149. 
